\title{
Tension-Free Vaginal Tape And Burch Colposuspension For Managing Stress Urinary Incontinence ( Types I And Ii ): A Comparative Clinical Trial.
}

\author{
M. H. El Shazly*, Nagwa A. Ghafar** \\ Urology Department, * El Sahel Teaching Hospital; Ob/Gyn Department,** \\ Al Azhar university (Girls), Cairo, Egypt.
}

\begin{abstract}
:
Objectives: To conduct a retrospective study of the clinical outcomes between tension-free vaginal tape (TVT) and Burch colposuspension for managing types I and II stress urinary incontinence (SUI) in women. Patients and methods: Between 1999 and 2002 a total of 32 TVT procedures and 43 Burch colposuspensions were used for managing 75 women with types SUI (types I and II) for a minimum follow-up period of one year. Results: The overall short-term (one year follow-up) success rates for TVT were $87.5 \%$ versus $90.7 \%$ for Burch colposuspension. The cure rates were sustained in the vast majority of patients during the short-term follow-up period (one year). Postoperative transient obstructive voiding dysfunctions were significantly more severe and common in Burch colposuspension (25.6\%) versus (15.6\%) for TVT. Further details of the clinical outcome and complications are presented. Conclusion: Both options are effective in managing SUI (types I and II) with comparable success rates. The success rate is marginally higher for the Burch colposuspension. However, the TVT procedure had shorter operative time, shorter hospital stay, fewer and milder complication rate, and is feasible under local anaesthesia. Nevertheless, the long-term results regarding the durability of the improvement rates are still to be further awaited for the TVT procedure.
\end{abstract}

Keywords: stress incontinence, tension-free vaginal tape, colposuspension.

\section{Introduction:}

More than a hundred different techniques are described for surgical management of stress urinary inconti nence (SUI) in women. This reflects the existence of no ideal option and the complex interplay of different factors in the pathogenesis of SUI. It follows that urologists has to be familiar and gain the experience of the main surgical techniques in order to be able to treat SUI in its different stages and types. The surgical options include retro-pubic colposuspensions, sling procedures, needle suspension techniques, periur - ethral injection of bulking agents, prosthetic sphincters, and tension-free vaginal tape (TVT) with the first two being the most invasive options. Burch colposuspension and pubo-vaginal autologous facial sling procedures are the most studied ones and are considered to be the gold standard options, against them all other options should be judged [1,2,3]. Burch colposuspension is recommended for types I and II SUI with no or minor intrinsic sphincteric deficiency (ISD) factor [4]. Pubo-vaginal slings are used

Refree : Prof ; Dr. Gamal Abou El- Serour. 
mainly whenever the main causative factor is ISD (type III) or in complicated recurrent cases [5]. Needle suspension techniques are more suitable for elderly women [6]. More recently, other less invasive options are available and include periurethral injections of different bulking agents [7], bone anchor suspension procedures [8] and the TVT procedure [9]. These forms the current platform for the armamentarium of surgical options available for surgical management of SUI whenever indicated.

\section{Aim of the work:}

To compare the clinical outcome of TVT procedure against the Burch colposuspension in the management of SUI (types I and II) in women.

\section{Patients and methods:}

Between 1999 and 2002 a total of 75 women (mean age 49.7 years) with urodynamiclly-proven SUI (types I and II) were managed surgically in two different centers, El Sahel Teaching Hospital, Cairo, Egypt; and Mouwasat Hospital, Dammam, Saudi Arabia. Burch colposuspension was done for 43 women (mean age 49.7 years) and TVT procedure was done for 32 women (mean age 53.6 years).

The study included only types I and II SUI who failed to respond to other medical conservative options. Urodynamically, genuine SUI is defined as involuntary urinary leakage with increased intra-abdominal pressure without associated detrusor contract ions. According to the classification of Blaivas, in types I and II the urinary leakage is due to urethral hypermobility without intrinsic urethral sphincteric deficiency [10]. In both, the baldder neck is closed at rest and urine leaks only during straining associated with urethral decent below the inferior margin of symphysis pubis. However, in type $\mathrm{I}$, the decent is less than 2 centimeters and there is no or minimal associated cystocele. In type II, the cystocele is more evident and the urethral decent is more than $2 \mathrm{~cm}$. In type III, the bladder neck is open at rest with maximum urethral closure pressure less than $20 \mathrm{~cm}$ water. The urine leaks with no or minimal stress and even by gravity due to deficient intrinsic sphincteric activity with no urethral hypermobility. In mixed SUI, the genuine SUI is associated with detrusor overactivity or hyper-reflexia. All cases with type III stress urinary incontinence (intrinsic sphincteric deficiency) or mixed SUI (detrusor overactivity + SUI) were excluded. Exclusion criteria included also patients with previous surgical management for SUI, and cases with previous major pelvic surgeries like abdominal or vaginal hysterectomy.

The preoperative work-up included a detailed medical history, physical examination, gynecologic examination, abdominopelvic ultraso und with estimation of post-voiding residual volume. The urodynamic assessment protocol included uroflow metry, filling cystometry, and urethral pressure profile at rest and during stress recording the leak point pressure ( Duet ${ }^{\circledR}$ Multi-P, Medtronic, Denmark ). The diagnosis of stress urinary incont inence was made whenever urine leakage occurred during coughing, or straining with no associated detrusor activity. The filling rate was $50 \mathrm{ml} / \mathrm{min}$ with the patient in a semi-sitting position. The same urodynamic evalua tion was repeated for all cases at 6 and 12 months postoperatively.

Our postoperative follow-up protocol included regular outpatient clinic visits at 4 weeks, and months 3, 6, 9, and 12. After 12 months, all patients were instructed to attend the urology 
clinic in case of any urological compl ain or yearly for longer-term follow-up. In each visit subjective assessment of patient's satisfaction, clinical examin ation, urinalysis, and pelvic ultrasound examination with full bladder and postvoiding were done.

For the 32 TVT procedures, the surgical technique followed the original one described by Ulmsten et al in 1996 [9]. The tape used is a synthetic polyp ropylene mesh tape (Ethicon Gynecare $^{\mathrm{TM}}$, UK). Spinal anaesthesia was used in $12 / 32(37.5 \%)$ patients, epidural anaesthesia in $9 / 32$ (28.1\%) patients, and local infiltration anaesthesia using an average dose of 40 $\mathrm{ml}$ of lidocaine $2 \%$ in $11 / 32$ (34.4\%) patients

With the patient in the lithotomy position, a midline anterior vaginal wall incision is made over the urethra with 18 Fr Foley's catheter in situ to facilitate urethra-bladder neck orienta tion. Creation of two para-urethral tunnels is then performed and the two TVT needles are then passed paraurethrally at a mid-urethral position and directed posterior to the symphysis pubis to come out through two separates small suprapubic incisions. Each needle-path is checked endoscopically to avoid and detect any bladder or urethral perforations. Then, both needles and the tape plastic covers are removed without exerting any tension on the tape. An on-table stress test is done through asking the patient to cough or strain with a bladder cont aining 250-300 $\mathrm{ml}$ of normal saline. Postoperatively, we did not fix urethral catheter routinely unless a bladder or urethral perforation has occurred or excessive dissections were performed. This occurred in 2/32 (6.3\%) patients where a urethral catheter was kept for 2-3 days and both voided freely after catheter removal.
The standard principles of Burch colposuspension [4] were followed using the modification described by Jarvis in 1994 [10]. Spinal anaesthesia was used for 18/43 (41.9\%) patients and epidural anaesthesia in 25/43 (58.1\%) patients. With the balloon of an $18 \mathrm{Fr}$ Foley's catheter at the bladder neck, the lateral wall of the bladder is identified and cleared laterally avoiding dissection of the urethra and bladder neck walls. Two to four size zero monofilament polypropylene sutures are then placed on each side to the paravaginal tissue. To assure sutures stability, each suture should entangle a good bite of fascia and vaginal wall without passing through the vaginal skin. Starting distally, the most distal suture is placed two centimeters lateral to the bladder neck level keeping about one centimeter inter-distance between each paired suture level. Then, each pair of leveled sutures is placed to its corresponding site into the Cooper's ligament (ileopectineal). Sometimes, the most distal suture has to be placed to the perios teum of the posterior pubis or the fibrous insertion of the rectus muscle. Care is to be given to avoid suture overtightening allowing the free insertion of a surgeon's index finger between the urethra and the symphysis pubis. Intraoperative stress test is then conducted by asking the patient to strain or cough to assure no leakage of urine. Then, a 20 Fr suprapubic cystocatheter and an 18 Fr urethral catheter are fixed for all patients. The urethral catheter is removed after five days. The patients learned how to open and close their suprapubic catheters. Starting on postoperative day five, we asked our patients to record-up a voiding diary through instructing them during day time to keep their suprapubic catheter closed and try to micturate normally on desire and record the voided volume. 
Then to re-open the suprapubic catheter and record the residual volume drained within five minutes after re-opening. The suprapubic catheter was removed when the residual urine is less than 50 $\mathrm{ml}$. The statistical analysis and compa rison of results were done using the Student ' $\mathrm{t}$ ' test with a $\mathrm{P}$ value consid ered significant when less than 0.001 .

\section{Results:}

Table (1), summarizes the overall patients, procedural, and clinical outcome data. Local anaesthesia was feasible in the TVT procedure being used for $11 / 32(34.4 \%)$ patients. Suprapubic drainage was used for all Burch cases for an average mean time of 8.9 days. In no TVT procedure, a suprapubic drainage was needed. There was no statistically significant diffe rence between both groups of patients regarding the age, the follow-up period, or the overall success rates. However, strong statistically significant differe nces were recorded regarding the mean hospital stay period, the mean operative time, the postoperative obstructive voiding dysfunctions, the overall post operative urological, and general surgical complications rates. The overall success rate for the Burch colposuspension was marginally higher being $90.7 \%$ (39/43 patients) versus
$87.5 \%$ (28/32 patients) for TVT. These rates remained durable without significant declines during the shortterm one year follow-up in both groups. The mean hospital stay was longer in Burch colposuspension group with a mean of 4.6 days versus 1.2 days in the TVT group with most of TVT cases done as day-cases (25/32 cases "78.1\%"). The mean operative time was shorter in TVT group being 25.6 (2054) minutes versus 67.9 (55-123) minutes for Burch colposuspension.

Obstructive voiding dysfunctions were significantly higher and severer among the Burch colposuspension group occurring in 11/43 (25.6\%) patients versus $5 / 32(15.6 \%)$ patients for the TVT procedure. No case of persistent retention of urine occurred among the TVT group versus 2/43 (4.6\%) cases among the Burch colposuspension group. Furthermore, the TVT group did not show cases of postoperative general complications versus 3/43 (7.0\%) cases for Burch group. Two cases of mild pulmonary atelectasis and one case of deep venous thrombosis. All the three cases responded well to conservative manag ement. No major complications or postoperative mortalities were recorded in both groups. 
Table [1] Patients, Procedural, and Clinical Outcome Data.

\begin{tabular}{|c|c|c|}
\hline & Burch Colposuspension & $T V T$ \\
\hline Number of Patients & 43 patients & 32 patients \\
\hline Age Mean (years) & 49.7 years $(31-66 \mathrm{Ms})$ & 53.6 years (36-64 months) \\
\hline Mean Follow-up Period & 17.1(13-43) months & $19.4(12-50)$ months \\
\hline $\begin{array}{l}\text { Anaesthesia: } \\
\quad \text { - Local } \\
\text { - Spinal } \\
\text { - Epidural }\end{array}$ & $\begin{array}{c}\text { None* } \\
\text { 18/43(41.9\%) patients } \\
25 / 43(58.1 \%) \text { patients. }\end{array}$ & $\begin{array}{l}\text { 11/32 }(34.4 \%) \text { patients. } \\
\text { 12/32 }(37.5 \%) \text { patients. } \\
\text { 9/32 (28.1\%) patients. }\end{array}$ \\
\hline Mean Operative Time & $67.9(55-123)$ minutes $*$ & $25.6(20-54)$ minutes. \\
\hline Mean Hospital Stay: & $4.6(3-12)$ days* & $\begin{array}{c}1.2(12-72) \text { days. } \\
25 / 32(78.1 \%) \text { as day-cases. }\end{array}$ \\
\hline $\begin{array}{c}\text { Post-operative Bladder Drainage: } \\
\text { - Urethral catheter } \\
\text {-Suprapubic catheter }\end{array}$ & $\begin{array}{c}\text { All Cases }(5 \text { days })^{*} \\
\text { All Cases }(\text { mean } 8.9 \text { days })^{*}\end{array}$ & $\begin{array}{c}\text { Not Routine }(2 / 32 \text { cases }) \\
\text { None }\end{array}$ \\
\hline $\begin{array}{l}\text { Success Rates: } \\
\text { - Complete Symptom Cure } \\
\text { - Marked Improvement. } \\
\text { - Improved. }\end{array}$ & $\begin{array}{l}29 / 43(67.4 \%) \text { patients. } \\
8 / 43(18.6 \%) \text { patients. } \\
\text { 2/43 (4.6\%) patients. }\end{array}$ & $\begin{array}{l}\text { 21/32 (65.6\%) patients. } \\
5 / 32(15.6 \%) \text { patients. } \\
\text { 2/32 (6.3\%) patients. }\end{array}$ \\
\hline Overall & $39 / 43(\mathbf{9 0 . 7 \%})$ patients & 28/32 (87.5\%) patients. \\
\hline $\begin{array}{l}\text { Failure Rates: } \\
\begin{aligned} & \text { - Persistent Retention } \\
& \text { - No Improvement. } \\
& \text { - Getting Worse. }\end{aligned}\end{array}$ & $\begin{array}{c}\text { 2/43(4.6\%) patients. } * \\
\text { 2/43(4.6\%) patients. } \\
\text { None }\end{array}$ & $\begin{array}{c}\text { None } \\
4 / 32(12.5 \%) \text { patients. } \\
\text { None }\end{array}$ \\
\hline $\begin{array}{l}\text { Success Durability at One Year: } \\
\text {-Recurrent SUI (of milder severity) }\end{array}$ & $\begin{array}{l}38 / 39(97.4 \%) \text { patients. } \\
1 / 39(2.6 \%) \text { patients. }\end{array}$ & $\begin{array}{l}26 / 28(92.9 \%) \text { patients. } \\
2 / 28(7.1 \%) \text { patients. }\end{array}$ \\
\hline
\end{tabular}

(*) Denotes statistically significant $P$ value less than 0.001 .

Table [2] Postoperative Complications.

\begin{tabular}{|c|c|c|}
\hline & Burch Colposuspension & $T V T$ \\
\hline $\begin{array}{l}\text { Urological Complications: } \\
\text { A) Obstructive Voiding Dysfunctions: } \\
\text { - Transient Retention. } \\
\text { - Transient de novo Urge } \\
\text { Total.. } \\
\text { B) Non-Obstructive: } \\
\text { - Bladder Perforation } \\
\text { - Urinary Tract Infection } \\
\text { - Mild Wound Infection } \\
\text { - Transient Mild Hematuria } \\
\text { Non-Urological Complications: } \\
\text { - Deep Venous Thrombosis } \\
\text { - Pulmonary Atelactasis. }\end{array}$ & 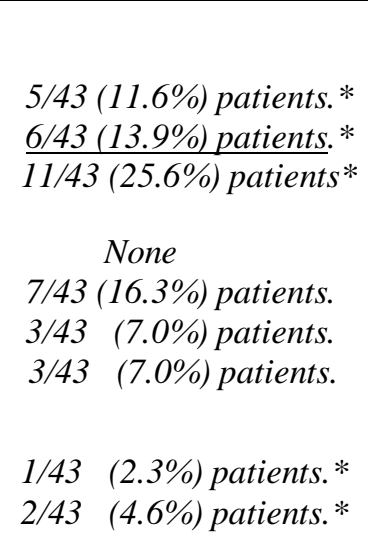 & $\begin{array}{c}\text { 2/32 (6.3\%) patients. } \\
\text { 3/32(9.4\%) patients. } \\
5 / 32(15.6 \%) \text { patients. } \\
\text { 2/32(6.3\%) patients. } \\
\text { 4/32(12.5\%) patients. } \\
1 / 32(3.1 \%) \text { patients. } \\
1 / 32(3.1 \%) \text { patients. }\end{array}$ \\
\hline
\end{tabular}

(*) Denotes statistically significant $P$ value less than 0.001 . 


\section{Discussion:}

The success of any surgical procedure in treating female SUI is judged by its long-term cure rates and its durability. The Burch colposuspen sion procedure had already passed the test of time, proved its efficacy, and durability of success rates. It is consid ered to be the gold-standard option for managing uncomplicated primary SUI types I and II [1,11]. It can also be used for managing cases with ISD (type III SUI), mixed SUI, and recurrent complic -ated cases with slightly lower success rates when compared to the pubovaginal sling procedures which form the gold-standard option for those cases [11].

The TVT procedure, its technique, and mechanism of action has been first described by Ulmsten in 1996 who found an $84 \%$ subjective and objective cure rate at two years with no signi ficant operative or postoperative complications [9]. It was introduced as a minimally invasive, day-case surgical option which can be done under local anaesthesia for managing female SUI. Its short-term reports are promising showing almost the same success rates of colposuspension with no significant tendency to decline on short-term follow-up [12-14]. Fewer longer-term studies up to five years has documented the efficacy and durability of this procedure [15]. It is estimated that some 250,000 TVT procedures have now been undertaken worldwide [16].

The results of this work showed that both the TVT procedure and the Burch colposuspension have compa rable success rates of $87.5 \%$ and $90.7 \%$ respectively. This comes in agreement with most of the reported studies in this concern [12-15,17-20]. Furthermore, this work documented the feasibility of using local anaesthesia for TVT. The mean operative time of the TVT procedure is significantly shorter than that of the Burch colposuspension (25.6 minutes and 67.9 minutes respectively). Moreover, the mean hospital stay period was much shorter for TVT (1.2 days) with most of the cases done as a daysurgery cases (25/32 "78.1\%") compar ed to 4.6 days for Burch group.

In both groups, the recorded success rates were durable on the shortterm one year follow-up period of this work. It is well documented that success rates of all surgical options for managing SUI tend to decline on longer follow-ups. Most of the studies report a decline of the cure rate from around $90 \%$ to $70 \%$ when followed for 7-13 years after the gold-standard Burch colposuspension [17-18]. A more decline may be logically expected with long-term results of the TVT procedure.

The postoperative complications of the TVT procedure compared to the Burch colposuspension were signific antly fewer and milder (table 2). This was more obvious for the obstructive voiding dysfunctions which were more common and severe in the Burch group $(11 / 43$ " $25.6 \% "$ in addition to 2 persistent retentions) versus the TVT group (5/32 "15.6\%", all transient with no persistent retentions). This fact is well documented in most of the reported literature [12-15,17-20]. However, small bladder perforations are known to occur more with the TVT procedure and usually recognized intraoperatively through monitoring the needle advanc ement endosocpically. This had occurred in 2/32 (6.3\%) TVT cases with no cases in the Burch group. The reported rate for bladder perforations in TVT is 5.4\% [19]. Our overall rates of postoperative complications were slightly higher than the reported rates 
which may be due to documenting all the adverse events whatever mild they were.

Finally, both the TVT procedure and the Burch colposuspension were reported to be used effectively for managing type III SUI, mixed SUI, and recurrent complicated SUI. However, the cure rates in these regards are more inferior with an average mean of $75 \%$ for the Burch colposuspension versus $45 \%$ for the TVT procedure [3,17-23].

\section{Conclusion:}

Both options, the TVT procedure and the Burch colposuspensions, are effective in managing SUI (types I and II). The success rate is marginally higher for Burch colposuspension. However, the TVT procedure had shorter operative time, shorter hospital stay, fewer and milder complication rates, and is feasible under local anaesthesia. The long-term results are still to be awaited regarding the durability of improvement rates for the TVT procedure.

\section{References:}

1. Alcalay M, Monga A, Stanton SL. Burch colposuspension: a 10- to -20 year follow-up. Br J Obstet Gynaecol 1995; 102: 740-5

2 Appell RA, Rackley RR, Dmochowski RR. Vesica percutan eous bladder neck stabilization. $J$ Endourol 1996; 10: 221-3

3 Blaivas JG, Appell RA, Fautl JA, et al. Definition and classification of urinary incontinence:Recommendations of Urodynamics Society. Neurourol Urodyn 1997a; 16: 149-51

4 Boustead GB. The tension-free vaginal tape for treating female stress urinary incontinence. BJU Int 2002; 89: 687-93
5 Burch JC. Urethrovaginal fixation to Cooper's ligament for correction of stress incontinence, cystocele, and prolapse. Am $J$ Obstet Gynecol 1961; 81: 281-90

6 Chaikin DC, Rosenthal J, Blaivas JG. Pubovaginal fascial sling for all types of stress urinary incontinence: long-term analysis. J Urol 1998; 160: 1312-16

7 Cross CA, Cespedes RD, McGuire EJ. Our experience with pubovaginal slings in patients with stress urinary incontinence. J Urol 1998; 159: 1195-8.

8 Drouin J, Tessier J, Bertrand PE, Schick E. Burch colposuspension: long-term results and review of published reports. Urology 1999; 54: $808-14$.

9 Dukett JDA. The use of periurethral injectables in the treatment of genuine stress incontinence. $\mathrm{Br} J$ Obstet Gynaecol 1998; 105: 390-6.

10 Hilton P, Mohammed KA, Ward K. Postural pain associated with perforation of the lower urinary tract due to insertion of a tension-free vaginal tape. $B r \mathrm{~J}$ Obstet Gynaecol 2002; 110: 79-82.

11 Jacquetin B. Use of "TVT" in surgery for female urinary inconti nence. J Gynecol Obstet Biol Reprod (Paris) 2000; 29: 242-7.

12 Jarvis GJ. Surgery for genuine stress incontinence. $\mathrm{Br} J$ Obstet Gynaecol 1994; 101: 371-4.

13 Leach GE, Dmochowski RR, Appell RA, et al. Female stress urinary incontinence guidelines panel summary report on surgical manag ement of female stress urinary inconti nence. J Urol 1997; 158: 875-80.

14 Nilsson CG, Kuuva N. The tensionfree vaginal tape procedure is succe ssful in the majority of women with indications for surgical treatment of urinary stress incontinence. $B r \quad J$ Obstet Gynaecol 2001; 108: 414-19.

15 Nilsson C, Kuuva N, Falconer C, Rezapour M, Ulmsten U. Long-term results of the tension-free vaginal tape (TVT) procedure for 
surgical treatment of female stress incontinence. Int Urogynecol J Pelvic Floor Dysfunction 2001; 12(Suppl): S5-S8.

16 Nitahara KS, Aboseif S, Tanagho EA. Long-term results of colpocysto urethropexy for persistent or recurrent stress urinary incontinence. $J$ Urol 1999; 162: 138-141.

17 Peatie AB, Stanton SL. The Stamey operation for correction of genuine stress incontinence in elderly women. $\mathrm{Br} \quad \mathrm{J}$ Obstet Gynaecol 1989; 96: 983-6.

18 Rezapour M, Ulmsten U. Tensionfree vaginal tape (TVT) in women with recurrent stress urinary incont inence: a long-term follow-up. Int Urogynecol J PelvicFloor Dysfunction 2001; 12 (Suppl): S9-S11

19 Rezapour M, Falconer C, Ulmsten U. Tension-free vaginal tape (TVT) in stress incontinence women with intrinsic sphincteric deficiency: a long-term follow-up. Int Urogynecol
J Pelvic Floor Dysfunction 2001; 12 (Suppl): S12-S14.

20 Rezapour M, Ulmsten U. Tensionfree vaginal tape (TVT) in women with mixed urinary incontinence: a long-term follow-up. Int Urogynecol $J$ Pelvic Floor Dysfunction 2001; 12(Suppl): S15-S18

21 Ulmsten U, Falconer C, Johnson P, et al. A multicenter study of Tension-Free Vaginal Tape (TVT) for surgical treatment of stress urinary incontinence. Int Urogynecol $J$ Pelvic Floor Dysfuction 1998; 9: 21013.

22 Ulmsten U, Henriksson L, Johnson P, Varhos G. An ambulatory surgical procedure under local anaesthesia for treatment of female urinary inconti nence. Int Urogynecol $J$ Pelvic Floor Dysfuction 1996; 7: 81-6

23 Ward KL, Hilton P. Prospective multicentre randomized trial of tension -free vaginal tape and colposuspension as primary treatment of stress incontinence. BMJ 2002; 325: 67-70 


\section{استخدام الثريط المهبلى بدون الثد او التعليق المهبلى لعنق المثانة}

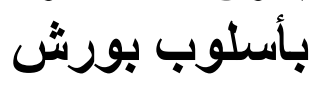

لعلاج السلس البولى الإجهادى (النوعين 1 و 2) عند السيدات:

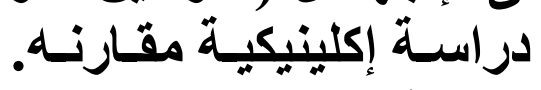

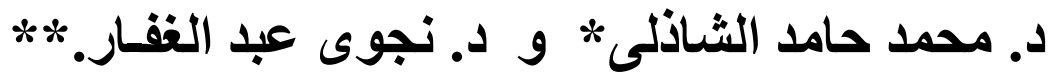

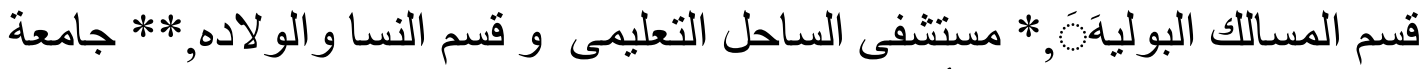
الأزهر "بنات", القاهرة, مصر .

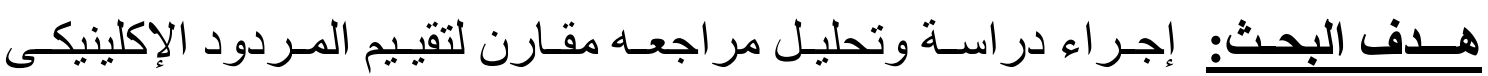

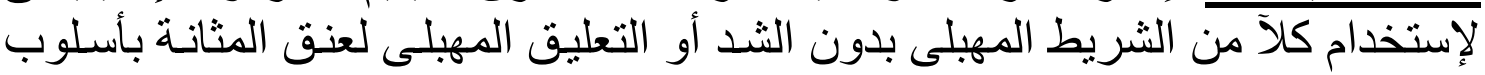
بورش لعلاج السلس البولى الإجهادى (النوعين 1 و 2) عند السئل السيدات.

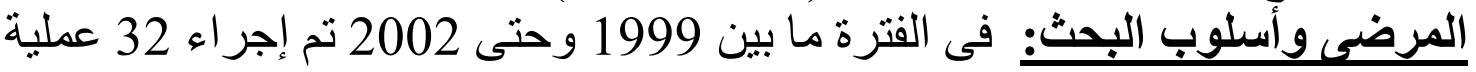

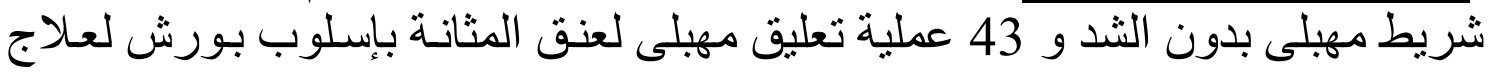

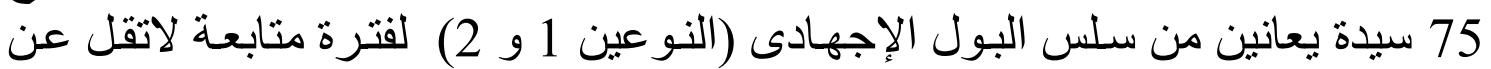

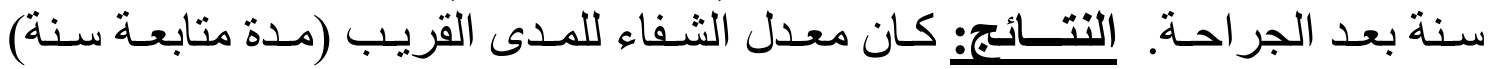

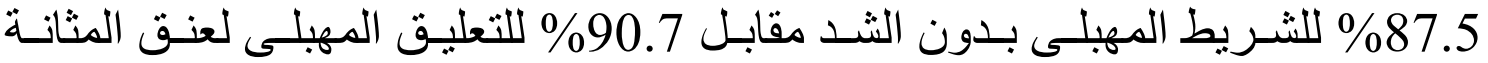

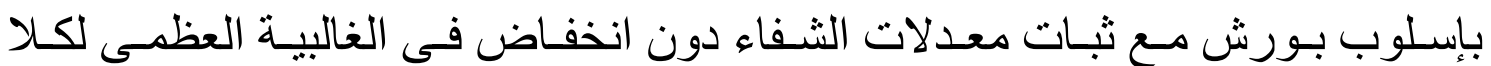

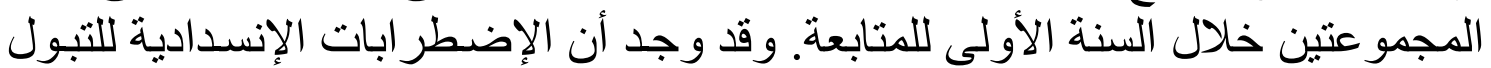

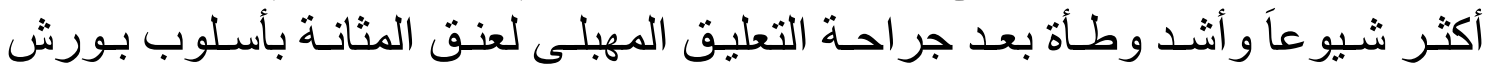

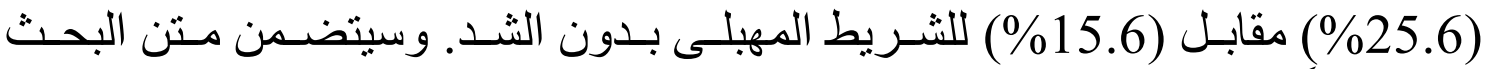

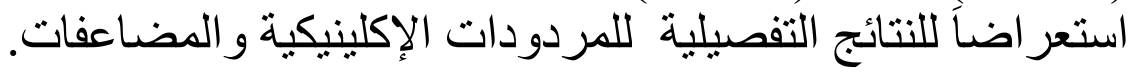

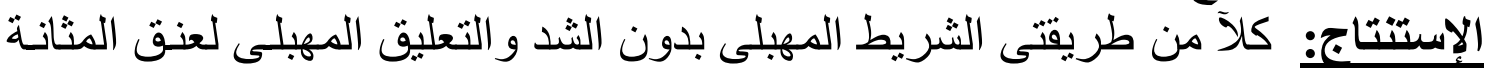

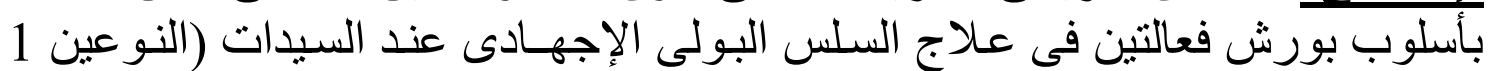

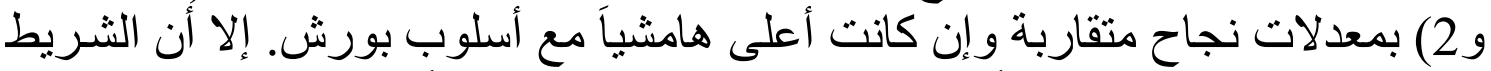

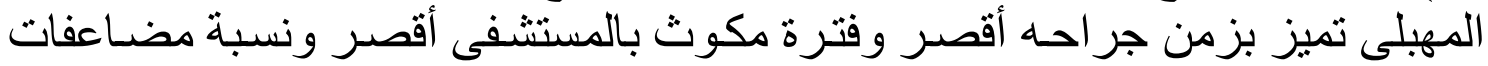

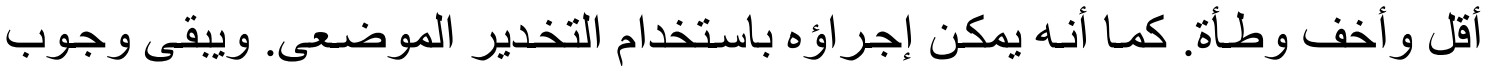

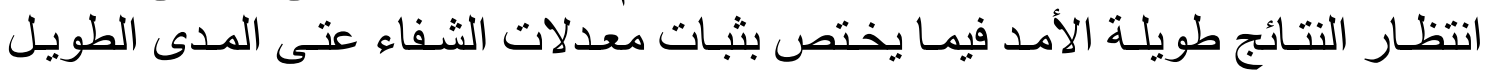
لجر احة الثريط المهيلى بدون الثند. 